\title{
Prospects and Continuity of Preschool and Primary Education in the Light of History and Modern Challenges
}

\author{
Yuliya Derkach, Svitlana Lozynska, Marta Prots
}

\begin{abstract}
The article is devoted to the analysis of the problem of ensuring the continuity of preschool and primary education on the example of the alternative educational institutions in the history of pedagogy. Moreover, the current state of the problem and recommendations for training of specialists of «Preschool Education» and «Primary Education» is taken into acount. The conditions and directions of ensuring the prospects and continuity in the education and training of preschool education and school are determined.
\end{abstract}

Keywords: comprehensive education of personality, principle of continuity and prospects, free education, preschool education, primary education, continuing education.

\section{Introduction}

In the context of the implementation of the reform requirements of all levels of education according to the requirements of the New Ukrainian School in Ukraine, a number of problematic issues arise that need to be addressed in the course of making certain changes. Among them there is the problem of continuity during the organization of the educational process at the levels of preschool and primary school education which have become particularly relevant in pedagogical science and practice.

Law of Ukraine «On Education» (2017), the Concept of the New Ukrainian School (2016), State Standards for Preschool (2012) and Primary General Education (2018), emphasize the importance of implementing a person-centered approach to the pedagogical process based on the principles of child-centeredness and the correspondence to the natural abilities. Therefore, one of the main tasks of educational reforms is to achieve integrity and real continuity between preschool and primary education.

The coherence of the first two levels of education does not mean that there are no more problems in the implementation of the principle of continuity between preschool and primary education. It is necessary to rethink the goals and content of continuity between preschool and primary 
education, their reorientation to address the problems of personalityoriented learning and education. To find ways in order to solve this problem, we propose to turn to the achievements of the history of pedagogy, namely the theory and practice of alternative educational institutions, as well as the ways of the solution of the problem of the continuity between preschool and primary education in accordance with modern law.

The purpose of the study is to reveal the basic principles and ways to ensure the continuity and prospects of the first two levels of education.

\section{Objectives of the study:}

1. To reveal the basic principles of ensuring the continuity and prospects of the first two levels of education on the example of alternative educational institutions.

2. Outline the problem of continuity between preschool and primary education at the present level.

3. Identify the main ways of the implementation of both preschool and primary education in accordance with current legislation.

\section{Theoretical basis}

The problem of continuity was studied by O. Zaporozhets, G. Lublinska, S. Rusova, V. Sukhomlynsky, E. Tikheeva, K. Ushinskyi; modern researchers Sh. Amonashvili, A. Bogush, T. Gushchina, N. Kirdyaeva, O. Kovalenko, A. Kurlat, V. Markova, N. Ponomareva, L. Shinkaryova and others.

The main principles of ensuring the continuity and prospects of the first two levels of education are illustrated on the basis of legislative documents: the Law of Ukraine «On Education» (2017), the Concept of the New Ukrainian School (2016), State Standards for Preschool (2012) and primary general education (2018) and others.

\section{Discussion}

The beginning of the experiments is associated with the emergence of secondary educational institutions, which were named - the new schools. At the turn of the XIX-XX centuries in Western Europe and America there were about twenty-five of them, most of which were based on the ideas of free education and bringing up.

In particular, these are:

a) «free schools» - «Prevo» (P. Robben), «Little Republic» (G. Lane), «Summerhill» (O. Neill), «Free School» (L. Hartmann) and others; 
b) «new» schools - «Abbotsholme» (C. Reddy), «Biedels» (J. Bedley), «De Roche» (O. Demolen), «Vickersdorf» (G. Vineken), etc;

c) schools of progressive education - «School of Professions» (J. Dewey), Dalton Primary School (E. Parkhurst), «Free School» (K. Stevenson), etc;

d) «home schools» - Schools of home education and upbringing (B. Otto, A. Schultz, etc.). As the research has shown, the proposed educational systems were not only models of free education and training (in various aspects), but also varieties of "personality pedagogy» (F. Hansberg, L. Gurlitt, G. Charrelman), supportive and correctional pedagogy (O. Decroly, M. Montessori, partly the ideas of R. Steiner), pedagogy of guardianship (humanism) (B. Otto, P. Petersen, P. Robben, S. Faure, O. Schulze), correctional pedagogy (G. Lane, O. Nill) (Barylo, 2004). They provided a complex indirect effect (without external coercion) on children and adolescents, provided their physical and spiritual growth. The specific conditions of the new school were formulated: the peculiarities of child's psychology, joint education, labour training, free activity of the child that meets the interests and needs, etc. were taken into account.

We can trace all this in the activities of new educational institutions. One of them is a school for boys, founded by Cecil Reddy (1858-1932) in 1889 in the countryside of Abbotsholme (England). The curriculum was dominated by scientific training. The pupils worked in workshops every day. A lot of time was devoted to sports, aesthetic education of pupils. The school had student self-government. Initially, the idea was to make this school a certain union of pupils, family, church, as if a state within a state. Only 11-year-old boys were admitted to the school in order to «live» in it for 8-9 years.

The motto of the school was: «Freedom is the submission to the law». C. Reddy was convinced that a fundamental pedagogical laboratory was needed for a fundamental change in school affairs, where «noble Englishmen» would be formed. This school had to solve two interrelated tasks: to develop the nature of each child and to adapt this nature to a certain type of subsequent activity of the pupil.General education provided at school was to ensure the harmonious development of the child, including physical education, work, the disclosure of creative talents, intellectual, moral, religious education into the educational process. In the course of their work, the students got acquainted with tailoring and shoemaking, cooking and jewelry and many other economic activities, whether agriculture or industry. With the aim of intellectual development up to 15 years, boys received general education based on the study of a wide range of theoretical disciplines, and from 15 years the number of subjects increased due to 
commercial, industrial and agricultural business (State Standard of Primary General Education, 2018, pp. 510-511). In the process of training, young people underwent a practical internship related to the future specialty. The main task of such an organization of school work was to arouse a healthy interest of students in nature and human life, the development of will and character, as well as the acquisition of a certain amount of practically necessary knowledge. Activity and ingenuity were especially encouraged at school. Hence, students themselves invented moving games, organized theatrical performances.

The activity of the Experimental Laboratory School, founded by the American philosopher-pragmatist and educator J. Dewey (1859-1952) in Chicago in 1896, was aimed at meeting the needs and developing the abilities of children. In the organization of school work Dewey demanded consideration of the basic impulses of natural growth of the child: social (need for communication with other people), constructive (need for movement during the game), research (need for knowledge and understanding of things); expressive (need for self-expression). Children from 4-5 years old to 14-15 years old studied in the laboratory school. The training course was divided into two-year stages. In general, the ideas of the American teacher contributed to greater consideration of the essence of children's nature in the educational process, the search for new forms of educational work (the results of such searches were complex programs, project method, etc.) (Levkivskyi, Dubasenyuk, 1999).

However, the name of $\mathrm{J}$. Dewey is associated with the idea of utilization of education in the American school, inreducing its intellectual saturation for most students. A well-known theorist of modern schools was the Swiss educator, professor at the University of Geneva Adolf Ferrier (1879-1960), who headed the International Association of Supporters of «New Schools» (1912), which formulated the general organizational and didactic rules of new schools (30 characteristic features). In 1899, A. Ferrier created the «International Bureau of New Schools». This «International Bureau of New Schools» became a center around which various areas of reformist pedagogy were grouped until the 1930s. The «International Bureau of New Schools» defined the general requirements for «new schools». These were boarding schools organized by private individuals or public pedagogical organizations. Schools should create an environment that ensures the physical, mental and moral development of children and prepares them for practical life (Levkivskyi and Dubasenyuk, 1999).

The School of Life (Hermitage) of the Belgian teacher and physician Jean-Ovid Decroly (1871-1932), established in 1907 in Brussels, gained notable popularity. In the elementary classes of the Hermitage, the so-called 
centers of interest played the role of the bases of education. The interest centers grouped the learning material according to the children's needs. They identified the needs for food, protection from bad weather, dangers, solidarity, recreation and self-improvement. Educational material was drawn from the environment - nature, school life, family, society. J.-O. Decroly began working with children with disabilities, and later founded a school for healthy children aged 3 to 18, calling it a «school for life, through life».

The task of teachers is to create a curriculum according to the interest centers. Thus, in school the child must find opportunities to establish their relationship with the social environment (school, family, society), with animals and plants.

J.-O. Decroly recommended to conduct all training by means of observation, association and practical (abstract and concrete) expression of the studied material. Excursions were widely used in the school of J.-O. Decroly. Modeling, handicrafts, drawing and other types of creative work were practiced. The teacher developed and proposed a number of didactic games, which he divided into series according to increasing difficulties (Matvienko, 1999).

Tested approaches to the organization of students' educational activities by J.-O. Decroly have shown an impact on Ukrainian teachers in the 1920s.

Thus, based on the generalization of the achievements of world pedagogy, in particular the schools: Abbotsholme of S. Reddy, the Laboratory School of J. Dewey, the activities of the «International Bureau of New Schools» of A. Ferrier and the School for Life of J.-O. Decroly, we can conclude that the principle of continuity at the stage of preschool and primary education is crucial. It should ensure a smooth, natural transition of the child from the position of preschooler to the position of junior high school.

Nowadays, the continuity should be seen as one of the fundamental principles of continuing education, which provides a gradual transition from the previous age to a new one, a combination of the child's newly acquired experience with the previous one. On the one hand, it provides the focus of educational work in the preschool institution on the requirements that will be imposed on children in school. On the other hand it presupposes the teacher's support for the level of development achieved by senior preschoolers; the knowledge, skills and experience of children acquired in the institution of preschool education and family; for their active use in the educational process, enables the holistic development of children's personality during training in the first two parts of the education system. 
This solution of the problem will solve the problem of continuity between preschool and primary education at the present level (Savchenko, 2011, p. 8).

The continuity creates a space for the implementation in the pedagogical process of preschool and primary school of a single, dynamic and promising system of education and training, which contributes to the convergence of conditions of education and training of senior preschoolers and younger students. Due to this, the transition to new conditions of schooling is carried out with the least psychological difficulties for children. This ensures their natural and comfortable entry into new conditions, which helps to increase the effectiveness of education and training of students from the first days of school. Preparing for school is an important part of an educator's job.

The positive consequences of the child's physical and sociopsychological development are studied and comprehended. At the present stage of development of the educational system in Ukraine, the strategic goal of preschool and primary education as the first steps in the system of continuing education is the development of the child's personality, acquisition of vital competence, its focus on creativity and self-realization. Holistic development of personality involves the development of the whole set of its qualities, which in the psychology of personality are grouped into four substructures: orientation, experience, mental processes, biopsychic properties.

According to current legislation and regulations, continuity is one of the prerequisites for continuity of education, which to some extent should ensure the unity, interconnection and consistency of purpose, content, methods, forms of education and upbringing, taking into account the age characteristics of children at adjacent levels of education. Nowadays, the legal framework for preschool and primary education is quite clearly defined. The Basic Component of Preschool Education and the State Standard of Primary Education determine the priority of the competency approach for solving the main tasks of preschool and primary education. These documents are designed to ensure the gradual formation of the child's personality, its physical, cognitive, social, aesthetic development, gaining some practical experience necessary for usage in future life (Bogush, Belenka, Yakymenko, 2012).

Conceptual principles of the reform of general secondary education «New Ukrainian School» (2016) for the period up to 2029 proclaim the construction of education at all levels with maximum consideration of individual physical, psychological, intellectual characteristics of the child of each age group. Among the key components of the New Ukrainian School formula we find: 
- new content of education, based on the formation of competencies necessary for the successful self-realization of the child in society;

- a thorough process of education aimed at the formation of sociomoral values;

- pedagogy based on partnership between student, teacher and parents;

- child-centeredness, focus on the needs of the pupil in the educational process;

- a new school structure that will promote the acquisition of new content and the formation of life competencies;

- a modern educational environment that will provide the necessary conditions, tools and technologies for teaching students, educators and parents in the educational institution and beyond.

Thus, we have outlined requirements for the organization at the state level, conditions and quality of education for both preschool and primary school - these first steps, the first links in the system of continuing education. Speaking about the methodological and theoretical principles of implementing continuity in the education system as a whole, it is important to emphasize first of all the general principles on which modern education is based and which relate both to preschool and primary school. They focus on the development of children's personality, which is the ultimate goal of improvement of all educational systems. The principles of humanization, integration, and differentiation are pervasive to them, and thus preschool and primary school are integrated into the system of continuing education.

Modern trends in preschool and primary education have much in common, in particular, focus on the characteristics of the child, creating favorable conditions for the formation of its proper orientation, selfawareness, positive self-esteem, self-esteem and respect for others, constructive motives, inclinations, needs of character, cognitive, mental processes, etc.

Therefore, the only strategic goal is the development of personality, vital competence of the child, its focus on creativity and self-realization. In this regard, we can compare the starting points outlined in the Basic Component of Preschool Education and in the State Standards of Primary Education for the unity of methodological principles. In particular, the State Standards clearly states that the primary school should continue the line of preschool development, consolidate and develop in the conditions of school education the heritage of preschool childhood. And this is an important step forward, which should demonstrate the evolutionary development of the child. Changing the social status of the baby does not mean that he, himself, has changed radically. Thus, we should not sharply differentiate between the 
goals and objectives of both stages of education (Bogush, Belenka, Yakymenko, 2012, p. 17; Clipa, 2014).

Coherence in defining the goals and dominants of the development of the child in both primary levels of education does not mean that there are no more painful problems at the regulatory level. These are primarily aspects related to the child's preparation for school.

In real practice and in science there are still differences in understanding the concepts of preparation for school, readiness for school, school maturity. The hierarchy of tasks for each stage of a child's life has not been definitively defined yet.

We proceed primarily from the fact that the traditional functional approach should be replaced by a pedocentric one, which focuses on the fullness of the child's life at each age. The previous paradigm of our education was based on a functional approach: a preschooler prepares for school, a schoolboy - for a higher education institution, so the child was considered from a functional position, depending on the change of its status in society. Both training requirements and research have already been adjusted for this.

The Concept of Continuing Education is based on the factors that determine the quality of the educational process, the principle of taking into account the individual, age and typological characteristics of each child. In particular, the parameters related to the education of preschool children are defined here: children who have turned 6 on September 1 of the current year and who according to the results of medical and psychological examination have no contraindications to systematic schooling enter primary school. Nevertheless, it is not possible to cover all six-year-olds with schooling, as it is necessary to take into account the level of readiness of children for this new activity (Draft Concept of Education Development, 2014).

Thus, preschool education should not see its main purpose only in preparing children for school. First of all, it should create the necessary conditions for the full realization of their abilities of five or six-year-old children, the improvement of their physical and mental development (Stadnenko, 2013).

The Concept takes into account the requirements defined by the Law and the Basic Component of Preschool Education. In particular, it states that every child before school must receive appropriate training that meets the requirements of the Basic Component of Preschool Education (2012). But it is known that today preschool, like school, develops not in a unified version of the same type, but in different types and variants.

This means that the implementation of the Basic Component can be carried out in various organizational forms. There is a question of scientific 
and practical nature: what the approaches to the training of preschool children and children who do not attend them should be like. According to the State Statistics Service of Ukraine, stated on January 1, 2019, there are 14.0 thousand preschool education institutions (legal entities) in Ukraine, which educate 1.3 million children. From them in the cities $-5,8$ thousand establishments $(39 \%)$ in which 970 thousand children $(75,9 \%)$ are educated. In rural areas 9,1 thousand establishments (61\%) in which 309 thousand children $(24.1 \%)$ are educated.

According to statistics, $74.4 \%$ (children aged 3-5) are covered by preschool institutions in Ukraine (83.7\% in cities; $56.2 \%$ in rural areas). The organization of school preparation for the remaining $25.6 \%$ of children is a scientific and normative problem. In previous experience, we have only one form of their solution - preparatory groups at schools (today, 1.8 thousand groups for preschool children are organized at secondary schools, which cover almost 24 thousand children).

Modern life has changed a lot, and at the moment it is important to make proper use of the possibilities of preschool education not ignoring the variable approach to this and the number of hours of training and the organizational conditions of its implementation (9. Concept of Education of Children of Early and Preschool Age, 2020)

But all this is only the external side of the problem of continuity, because there are more significant aspects that aim us to understand this very concept. From the psychological point of view, it is necessary to highlight the aspects well developed in the Basic Component (2012), which puts the child at the center of pedagogical efforts, reveals his personality «Child's personality», "Child in the natural environment», «Child in society». They do not transfer the preparation for learning to the subject level, but use the indirect influence of different activities in order to carry out speech development, development of imagination and thinking, spatial representations of children and so on. It is a departure from subjectcentrism and a holistic view of the usage of opportunities in various spheres of preschool activities, which should ensure the appropriate level of socialization, emotional and speech development of the child, his selfrealization and so on.

The State Standard of Primary Education (2018) outlines the following key competencies: fluency in the state language, ability to communicate in native and foreign languages, mathematical competence, competencies in natural sciences, engineering and technology, innovation, environmental, information and communication, cultural, civic and social competence, entrepreneurship and financial literacy, lifelong learning. These competencies are formed on the basis of competencies inherent in preschool 
age: health, communication, subject-practical, play, sensory-cognitive, natural-ecological, artistic-productive, speech, social and personalassessment (according to the Basic component of preschool education).

Leading activities of senior preschool children (communication, play, movement, cognitive, household, artistic and aesthetic (modeling, drawing, application, design, listening to music, singing, choreography, theatrical) should be preserved and enriched in primary school This will allow a gradual transition to learning as a new leading activity in the first (adaptive-playful) period of primary education.

Common to all key competencies are cross-cutting skills such as reading comprehension, the ability to express one's opinion orally and in written form, critical and systematic thinking, creativity, initiative, the ability to justify a position logically, the ability to manage constructively emotions, assess risks, make decisions, solve problems, collaborate with others. The formation of key competencies of children in primary school make the base for the basic qualities of the child's personality acquired in preschool age: observation, curiosity, arbitrariness, independence, initiative, responsibility, sensitivity, creativity, interpersonal positive communication and others.

According to the State Standard of Primary Education (2018), the educational process in primary school is organized in cycles, taking into account the age characteristics of physical, psychological and mental development of children aged 6-10 years. The first cycle of primary education - adaptive-game (1-2 forms); the second cycle - the main (3-4 forms). This innovation creates the preconditions for a gradual psychological and comfortable transition of the child from play to learning, which are the leading activities of children in preschool and primary school age, respectively.

Thus, if preschool education today has changed qualitatively in terms of understanding the essence of the child's preparation for school and the realization of the age opportunities in the sixth year of life, then primary school can not remain within its old notions of relying only on the subject readiness of their youngest pupils teaching. We must create such conditions in primary school that those qualities, skills, achievements of preschool, the formation of which has not yet been completed at the level of preschool age, could fully develop in primary school and at the same time contribute to the formation of priority, leading activities (Zagarnytska, Belenka, Boginich, 2009).

The range of didactic methods and techniques for teachers should be expanded with developmental games and exercises, logic problems, problem questions, game technologies that activate children's thinking and 
imagination. It is necessary to organize systematic observations, research activities, using the development environment of the group / class.

In the educational process of both preschool and primary school, communication between an adult and children in the form of dialogue should be the leading one. At the same time, the adult must recognize the child's right to proactive statements, reasoned defense of their proposals, the right to make mistakes. This will promote the development of the child's activity, initiative and self-esteem. It is advisable to create emotionally significant situations, to maintain dialogic communication between children.

It is also important to provide the child with the opportunity to interact and share experiences with peers and adults. Then children will be able to show initiative, creativity, imagination, responsibility on the basis of their experience.

Preschool teachers should activate children's thinking, promote conscious perception and assimilation of familiar and new information, encourage them to ask questions, make assumptions, find independent solutions, check their correctness and more.

Conducting the organized educational and cognitive activities it is important to use systematically a variety of classical and innovative pedagogical technologies, methods and techniques that have proven themselves in modern didactics, to combine rationally verbal, visual and practical methods (Instructional and methodical recommendations, 2018).

Preschool teachers, thinking about the prospects of child development, should create the conditions for better entry of young students into full-fledged educational activities. This means creating a precondition for a 6-year-old child to form an organization, basic prognosis, the ability to be aware of their actions and work in a random mode, and so on. The guideline here, of course, is the requirements of the section «Formation of general educational skills and abilities», which opens the curriculum of primary school (State Standard of Primary General Education, 2018).

If we talk about why primary teachers should learn from preschooler ones, we should first highlight the aspect that is insufficiently developed in primary school. These are, in particular, various means of implementing an individual approach to the child. Personality-oriented approach is, in fact, a long-known principle in pedagogy of individualization and differentiation. The new orientation of the pedagogical system is based on deep knowledge of the child.

And if preschool teachers are well aware of this, then primary school teachers still need to learn a lot, to convince them of the benefits of meaningful psychological study of each student. Our leading tasks can be outlined in one key phrase: «From the management of each educational 
institution to the management of the education of each child» (Savchenko, 2011).

The modern vision of solving the problem of continuity is to create conditions for the implementation in the educational process of preschool and secondary schools of a single, dynamic, promising system of personal creative growth of the child.

Ensuring the effectiveness of such a system should include:

1. Establishing cooperation between the preschool and secondary school on the basis of a cooperation agreement, which defines the purpose of cooperation, rights and responsibilities of the preschool and school. The agreement is signed by the heads of educational institutions every year in August.

2. Discussion, preparation and approval of the annual plan of joint work between the preschool and secondary school.

\section{Results}

Approximate scheme of interaction between preschool and secondary school:

- educational monitoring of educational quality by educational institutions (systems of consistent and systematic measures carried out within the annual work plan to identify and track trends in the quality of education in educational institutions, establishing compliance with actual results of educational activities to its stated objectives, and assessing the degree, direction and causes of deviations from the goals);

- drawing up a plan of joint activities in accordance with the tasks that need to be solved at a particular stage of work;

- holding round tables with the participation of administrations and methodological services of educational institutions, parents of children of future first-graders;

- approval of a joint action plan at methodological associations of primary school teachers and educators of preschool education institutions.

The main directions of methodical work in order to ensure interaction:

1) mutual attendance of open classes in preschool institutions and lessons in primary school;

2) questionnaires for teachers of preschool and secondary schools on the issues of comprehensive development of the child's personality;

3) holding Open Days in preschool and general educational institutions for parents of senior preschool children, educators of preschool institutions and primary school teachers;

4) participation in joint pedagogical councils, workshops, round tables, conferences, consultations, thematic exhibitions, etc.; 
5) joint methodological associations of creative groups of educators of preschool education institutions and primary school teachers;

6) involvement of teachers of both preschool and primary school to participate in joint pedagogical projects, development of guidelines and advice;

7) mutual exchange of accumulated pedagogical experience between educators of senior preschool children and primary school teachers on interesting issues of succession of continuity;

8) self-education of teachers of preschool and primary school, professional development;

9) interaction of preschool teachers and primary school teachers on the implementation of continuity in three areas: informational, educational, methodological and practical.

10) development of individual, collective and non-traditional forms of methodical work in increasing the level of competence of teachers in solving the problem of continuity of game forms of educational activity of preschoolers and primary school pupils.

Work with senior preschool children and elementary school pupils includes:

- conducting excursions to the school;

- organization of joint exhibitions of children's works, competitions, etc. both in preschool and secondary schools;

- visiting theatrical performances, museums both in preschool and secondary schools;

- visiting by children of senior preschool age the holiday of September 1 ( the beginning of the school year) dedicated to the Day of Knowledge, the holiday «Farewell to the Primary School» and other events in the secondary school; activities, etc.

- joint participation of schoolchildren and preschoolers in project

Work with parents involves:

- meetings of primary school teachers with parents of pupils of senior preschool groups at parent meetings;

- conducting Internet meetings, Internet consultations, webinars, forums for parents of future first-graders;

- acquaintance with the psychological patterns of development of the child of senior preschool and primary school age;

- questionarie of parents of future first-graders on the personal growth of children, the level of preschool maturity for counseling;

- organization of work of «pedagogical living room» for parents of pupils of senior preschool age concerning preparation of children for school; 
institution;

- organization of Open Days for parents in a general educational interaction.

- organization of work of Parents' clubs and other forms of

The activity of both psychological services of preschool and general secondary education institutions also requires coordination of actions. Interaction of preschool and primary education institutions in the work of social and psychological services may include:

- implementation of a single psychological and pedagogical control over the dynamics of children's development;

- study of the level of development of basic personality traits of senior preschool children as a condition for successful learning in primary school;

- analysis of the conditions for successful adaptation of first grade students to school life;

- application of correctional and developmental methods while working with children of senior preschool and primary school age who need an individual approach;

- conducting joint methodological activities.

The success of interaction is determined by a number of factors created by pedagogically competently organized developmental, educational environment that meets the psychological and physiological characteristics and physical capabilities of children.

Work on the organization of continuity should be carried out by pedagogical teams jointly and systematically. Only the interest of both parties and the parent community will solve the problems of continuity of preschool and primary education, will make the transition from preschool to primary school painless and successful for the child (Instructionalmethodological recommendations, 2018).

\section{Conclusions}

Thus, the task of the school is to educate an educated, cultured, comprehensively developed person who will create in the new millennium. Preschool, as the first link - cannot but respond to significant changes in the development of primary school. Preschool teachers must ensure that the child is ready to go to school, and it is determined by the fact that the child, while still a preschooler, understands the need to prepare for school. The joint work of preschool educators, teachers and families in preparing preschoolers for school is important here (Stadnenko, 2013, p. 5). 
Summarizing the above, we can say that the main condition for ensuring the prospects and continuity in education and training is the focus of the pedagogical process of preschool and school on the comprehensive development of the child's personality. Given this, it is necessary to link curriculum, methods and forms of education in preschool and primary school.

Let's outline the main areas of continuity in the education of preschoolers and primary school children:

- determining the prospects in learning from preschool to the end of primary school; subordination of its purpose and tasks to each of these age periods;

- constructing the main educational lines of study in the 1 st grade, taking into account all the experience gained in preschool childhood;

- giving priority to the development of productive and creative types of both educational and artistic speech activities as a basis for the formation of productive imagination and creative thinking, children's independence, initiative;

- ensuring the connection of the leading activities of adjacent periods of study, reliance on the relevant for this age period type of activity;

- creating conditions for the formation of elements of the leading activities of the next age period.

Higher education institutions face the task of training new generation specialists. Teachers and educators must be ready to build an educational space in the school and preschool institution, consistent with the values of humanistic philosophy, psychology and pedagogy. This presupposes not only the formation of humanistic values in future teachers, their personal maturity, broad outlook, high level of education, but also practical ability to create an appropriate educational environment, build relationships with students on a partnership basis, ability to understand themselves and others, specific situations. The stated humanistic values of education, ideas of personality-oriented pedagogy, practice of psychological and pedagogical support, humane pedagogy, pedagogy of understanding and partnership should form the basis of professional training of future teachers of schools and preschools.

Modern education requires developed reflective skills of teachers and educators, which must be formed at the stage of education in higher education and manifested in the age and individual characteristics of children, organizational and semantic characteristics of the educational process. Successful professional activity of a modern teacher is impossible without the ability to quickly navigate in a significant flow of information, without the active use of modern technologies. 
Professional document management should be optimized in order to free up time for effective organization of pedagogical work. Computer literacy of teachers is a condition for their rapid orientation in the information space, participation in domestic and international professional cooperation, successful lifelong learning. In the context of continuing education, teachers of primary and preschool education need to improve constantly their professional level (Concept of education of children of early and preschool age, 2020).

When training specialists of «Preschool Education» and «Primary Education», lecturers in higher educational institutions should follow the offered tips while working with students:

- to form students' creativity, creativity, responsibility;

- to involve them in active independent cognitive activity;

- to acquaint with normative documents of preschool and primary education, to train them for the correct selection of didactic methods, receptions, means, forms for maintenance of continuity;

- to emphasize to future primary school teachers the use of game techniques, continue to form pupils' creative imagination, thinking, do not set homework of an educational nature, conduct a lesson of 35 minutes;

- to make the use of authoritarian style in communication with children unacceptable.

Thus, the continuity of preschool and primary education is ensured by the unity of approaches to the organization of life of a child of six and seven years of age, regardless of socio-pedagogical conditions of education: preschool, first grade, primary school group, family education and more. The activities of educational institutions to ensure continuity should be carried out by pedagogical teams jointly and systematically.

The joint efforts of pedagogical teams of preschool and general secondary education institutions and the parent community will ensure a psychologically balanced and successful transition for the child from the previous level - preschool education, to the next - primary education, and the presence of internal communication in the content of educational work, forms of organization of activities in preschool and primary school provides the integrity of the process of development, education and upbringing of the child.

\section{References}

Barylo, O. A. (2004) Ideas of free education in the reformist pedagogy of the late nineteenth - first third of the twentieth century. (Doctoral dissertation). National Pedagogical Dragomanov University, Kyiv. 
Bohush, A.M., Byelyen'ka, H.V., Bohinich, O.L., Havrysh, N.V., Dolynna, O.P., ... Yakymenko, L.YU. (Eds.) (2012). The basic component of preschool education. Preschool education, 7, 4-19.

Clipa, O. (2014) Social and Emotional Development of Pre-schoolers, The actual Problems of the Theory and Practice of Modern Pre-School Education in Poland, Romania and Ukraine, (Coord. Otilia Clipa, Maria Oliznik si Malgoryata Stawiak-Ososinska) - Ed. Lumen Media Publishing, London, 2014.

State standard of primary general education. № 87 (2018) https://www.kmu.gov.ua/npas/pro-zatverdzhennya-derzhavnogostandartu-pochatkovoyi-osviti

Zaychenko, I. V. (2010). History of pedagogy. History of foreign pedagogy. Kn. 1. Kyiv: Slovo.

Law of Ukraine «On Education». https://zakon.rada.gov.ua/rada/show/2145-19

Instructional and methodical recommendations «On ensuring the continuity of preschool and primary education», 1/9-249 (2018). https://mon.gov.ua/ua/osvita/doshkilna-osvita/nastupnist-mizhdoshkilnoyu-ta-pochatkovoyu-osvitoyu

History of pedagogy. Course of lectures (2004). http://www.info-library.com.ua/booksbook-69.html

Ferenets', V.B. (2020). The concept of education of children of early and preschool age. Kyiv: FOP

Levkivs'kyy, M. V., Dubasenyuk, O. A. (Eds.) (1999) History of pedagogy. Zhytomyr: ZHDPU.

Matviyenko, P. I. (Ed.) (1999). Pedagogical technologies. Experience. Practice. Poltava

Conceptual principles of secondary education reform (2016). https://www.kmu.gov.ua/storage/app/media/reforms/ukrainska-shkolacompressed.pdf

Draft Concept of Education Development for the period 2015-2025. http://osvita.ua/news/43501/

Savchenko, O. YA. (2011) Continuity and perspective in the work of the first two levels of education. Preschool.education, 11, 8-10.

Stadnenko, N. (2013) The child's readiness for school: components of successful learning. Elementary School, 9, 3-5. 